\title{
Pembinaan Ketahanan Pangan Santri Pesantren Al-Quran "Bina Insan" Di Masa Pandemi Covid-19 Melalui Budidaya Terpadu Ikan Dan Sayuran Melalui Metode Akuaponik
}

\author{
Mukhzarudfa $^{1^{*}}$, Wirmie Eka Putra ${ }^{1}$, Dedy Setiawan ${ }^{2}$ \\ ${ }^{1}$ Fakultas Ekonomi dan Bisnis, Universitas Jambi, Indonesia \\ ${ }^{2}$ Fakultas Sains dan Teknologi, Universitas Jambi, Indonesia \\ Email Korespondensi: dedy_setiawan@unja.ac.id
}

\begin{abstract}
ABSTRAK
Saat ini dunia sedang di landa wabah penyakit yaitu Pendemi Covid-19, hampir semua negara di belahan dunia ini merasakan dampak dari wabah ini, tidak terkecuali di negara Indonesia. Dampak pendemi covid-19 ini memberikan efek yang luar biasa bagi setiap negara yang ada dan berkemungkinan dapat terjadinya bencana kelaparan di setiap negara akibat adanya isolasi mandiri dan pembatasan sosial berskala besar dengan tujuan untuk membatasi penyebaran wabah ini lebih luas lagi. Dalam mengahadapi dampak ini, banyak negara-negara yang ada di dunia membuat beberapa kebijakan-kebijakan baru, demi untuk dapat menyelamatkan masyarakatnya. Salah satunya negara Indonesia. Pemerintah Indonesia melalui Kementerian pertanian Republik Indonesia (RI) membuat kebijakan baru yaitu Agenda SOS/Emergency (agenda darurat) dalam bentuk menjaga ketahanan pangan dengan tujuan agar masyarakat di Indonesia dapat lepas dari bencana kelaparan akibat pandemic covid-19 ini. Berdasarkan survey dan Hasil studi pendahuluan, ditemukan ada beberapa permasalahan di sekolah mitra, yaitu: (1.) Masih banyak guru-guru yang ada di pesantren mitra ini, belum menegetahui kebijakan-kebijakan pemerintah dalam menghadapi wabah pendemic Covid-19 di masa New Normal. (2) Pesantren Mitra pada saat ini belum memiliki inovasi yang nyata untuk dapat menjaga ketersedian pangan bagi kebutuhan para santri-santri yang ada. Kegiatan pengabdian IPTEK yang akan diberikan adalah 1) Peningkatan pengetahuan Guru tentang Kebijakan pemerintah di masa New Normal, 2) Pelatihan dan pembuatan Inovasi Ketahanan pangan berupa Budidaya Terpadu Ikan dan Sayur mengunakan metode Akuaponik. Kegiatan pengabdian ini diberikan dalam bentuk pelatihan. Metode yang digunakan adalah: ceramah, tanya jawab, sharing ide, praktik/latihan mengenai cara mengimplementasikan dan memelihara inovasi ketahanan pangan tersebut. Lokasi kegiatan pengabdian diselenggarakan di Pesantren Bina Insan Bagan Pete Kec. Alam Barajo.
\end{abstract}

Kata kunci: New Normal, Covid-19, Ketahanan Pangan, Budidaya Ikan Dan Sayur.

\section{PENDAHULUAN}

Saat ini dunia sedang di landa wabah penyakit yaitu Pendemi Covid-19, hampir semua negara di belahan dunia ini merasakan dampak dari wabah ini, tidak terkecuali di negara Indonesia. Dampak pendemi covid-19 ini memberikan efek yang luar biasa bagi setiap negara yang ada dan berkemungkinan dapat terjadinya bencana kelaparan di setiap negara akibat adanya isolasi mandiri dan pembatasan sosial berskala besar dengan tujuan untuk membatasi penyebaran wabah ini lebih luas lagi.

Dalam mengahadapi dampak ini, banyak negara-negara yang ada di dunia membuat beberapa kebijakan-kebijakan baru, demi untuk dapat menyelamatkan masyarakatnya. Salah satunya negara Indonesia. Pemerintah Indonesia melalui Kementerian pertanian Republik Indonesia (RI) membuat kebijakan baru yaitu Agenda SOS/Emergency (agenda darurat) dalam 
bentuk menjaga ketahanan pangan dengan tujuan agar masyarakat di Indonesia dapat lepas dari bencana kelaparan akibat pandemic covid-19 ini. (Alamsyah, 2020)

Selain menjaga ketahanan pangan, upaya yang di lakukan oleh pemerintah Indonesia saat ini dengan memberlakukan New Normal dengan tujuan agar dapat memulihkan sosial ekonomi masyarakat yang ada di Indonesia sehingga dengan adanya kebijakan-kebijakan ini diharapkan dapat menjamin ketahanan pangan di Indonesia dan negara Indonesia dapat terhindar dari dampak buruk akibat dari pandemi yang dikuatirkan bisa terjadi pada setiap negara yang ada didunia pada masa pendemi covid-19 ini.

Upaya dalam menjaga ketahanan pangan di masa pandemic covid-19 ini, pemerintah Indonesia melalui seluruh perguruan tinggi yang ada di Indonesia untuk dapat membuat terobosan-terobasan atau invosasi agar dapat menjamin kesedian pangan di masyarakat dimasa di berlakukannya kebijakan new normal ini (SB-IPB, 2020).

Kegiatan yang akan dilaksanakan dalam pengabdian ini, merupakan salah satu bentuk terobosan yang dilakukan oleh perguruan tinggi Universitas Jambi dalam menjaga kesediaan ketahanan pangan sesuai dengan apa yang diinginkan oleh pemerintah Indonesia dengan memberikan pelatihan dan pembuatan budidaya terpadu ikan dan sayuran melalui metode akuaponik.

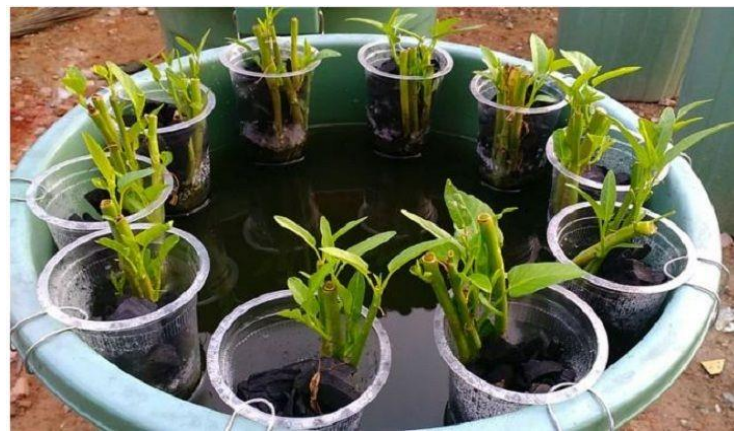

Gambar 1. Budidaya Terpada Ikan dan Sayuran Melalui Metode Akuaponik

Kegiatan ini akan dilaksanakan di salah satu pesantren di Kota Jambi yaitu pesantren Bina Insan. Pesantren Bina Insan merupakan sebuah pesantren yang telah ada dari tahun 2018. Ketua Yayasan pesantren ini adalah Dr. H. Muhammad Nurung., Lc. M.Ag. Pesantrean Bina Insan pada saat ini hanya menampung santri laki-laki saja. Santri yang ada di pesantren ini berlatar belakang ekonomi yang berbeda-beda, namun hampir $70 \%$ santri yang ada di pesantren ini berasal dari tingkat ekonomi orang tua yang sangat rendah.
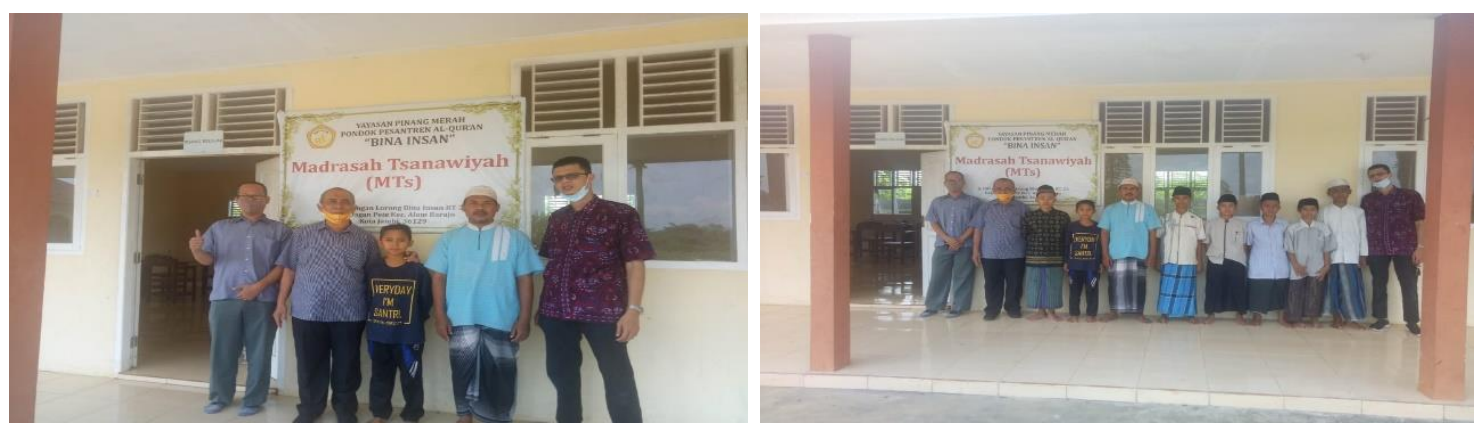

Gambar 2. Mitra dari kegiatan Pengabdian

Berdasarkan hasil diskusi awal yang dilakukan oleh tim pengabdian ini dengan pihak pengelolah pesantren. Di masa pandemic covid-19 ini, pihak pengelola pesantren juga merasakan dampak yang luar biasa terkhusus dalam kebutuhan pangan untuk pesantren 
tersebut. Apalagi dengan latarbelakang ekonomi orang tua santri yang rata-rata rendah dan pembatasan sosial sehingga adanya keinginan ataupun harapan dari pihak pengelola pesantren terhadap perguruan tinggi khususnya Universitas Jambi dapat memberikan inovasi untuk dapat menjaga ketersediaan pangan pada pesantren Bina Insan ini.

Berdasarkan prasurvey dan hasil diskusi tim pengabdian dengan pengambil kebijakan di Pesantren Mitra pengabdian. Maka didapati permasalahan utama yang dihadapi oleh pesantren mitra dalam pengabdian ini, yaitu :

1. Masih banyak guru-guru yang ada di pesantren mitra ini, belum menegetahui kebijakan-kebijakan pemerintah dalam menghadapi wabah pendemic Covid-19 di masa New Normal.

2. Pesantren Mitra pada saat ini belum memiliki inovasi yang nyata untuk dapat menjaga ketersedian pangan bagi kebutuhan para santri-santri yang ada .

Dengan adanya masalah tersebut, mitra membutuhkan workshop dan pelatihan terhadap guru-guru dan santri di pesantren mitra bagi meningkatkan pengetahuan mereka akan kebijakan-kebijakan pemerintah dalam menghadapi wabah pendemi covid-19 dimasa new normal dan kemampuan mereka dalam membuat sebuah inovasi khususnya budidaya terpadu ikan dan sayur mengunakan metode Akuaponik. Dengan diadakan pengabdian ini, diharapkan oleh pihak pesantren dapat membantunya dalam menghadapi ketersediaan pangan untuk pasantren mereka.

\section{METODE PELAKSANAAN}

Berdasarkan permasalahan yang terjadi pada mitra tersebut, Metode pelaksanaan pada pengabdian kepada mitra ini, dimulai dari proses identifikasi kebutuhan dari mitra,, pengenalan kebijakan, demonstrasi pembuatan inovasi serta Evaluasi Adapun langkahlangkah yang dilakukan dalam pengabdian ini adalah sebagai berikut:

\section{Tahap awal untuk meningkatkan pengetahuan Guru-Guru akan kebijakan pemerintah New Normal di masa Pademic Covid-19}

Pada tahap ini dilakukan beberapa sub kegiatan antara lain:

1. Melakukan survey awal untuk mengetahui pengetahuan peserta khususnya guru-guru di Pesantren Mitra. Kegiatan ini dilakukan dengan melakukan wawancara secara langsung kepada guru-guru tentang pengetahuan tentang kebijakan pemerintah di masa new normal yang diketahui baik yang diperoleh dari hasil belajar maupun mendengar secara langsung maupun tidak langsung meliputi: prinsip, metode, dan prosedur dalam melaksanakan kebijakan New Normal.

2. Pemberian materi kebijakan-kebijakan pemerintah dalam bentuk ceramah

3. Evaluasi akhir dari kegiatan ini dilakukan dalam rangka untuk mengetahui tingkat pemahaman mitra terhadap materi yang telah diberikan.

\section{Tahap meningkatkan pengetahuan Guru-Guru dalam Membuat Inovasi Ketahanan Pangan}

Pada tahapan kedua ini dilakukan beberapa aktivitas antara lain:

1. Melakukan survey awal untuk dapat mengetahui tingkat pengetahuan peserta khususnya guru-guru di pesantren Mitra. Kegiatan ini dilakukan dengan melakukan wawancara secara langsung kepada guru-guru tentang inovasi untuk ketahanan pangan yang mereka ketahui selama ini baik hasil pelatihan maupun secara langsung maupun tidak yang meliputi: "prinsip, metode, dan prosedur" dalam pembuatan inovasi ketahanan pangan

2. Pemberian materi inovasi ketahanan pangan untuk ketersediaan pangan dengan cara ceramah 
3. Evaluasi akhir dilaksanakan dengan tujuan untuk mengetahui secara pasti tingkat pemahaman guru terhadap materi yang telah diberikan.

\section{Tahap Demontrasi Pembuatan Inovasi Budidaya Terpadu Ikan dan Sayur}

Pada tahap pelaksanaan aktivitas ini dilakukan beberapa kegiatan, yaitu:

a. Memberikan bantuan bibit sayuran, ikan, ember, pakan ikan dan alat pendukung ternak ikan secara langsung kepada ketua yayasan yang disaksikan oleh guru dan santri di pesantren mitra.

b. Pemberian materi cara pembuatan budidaya terpadu dengan cara praktek dan ceramah

a. Evaluasi akhir dilaksanakan dengan tujuan untuk mengetahui secara pasti tingkat pemahaman guru terhadap materi yang telah diberikan.

Tahapan pelaksanaan kegiatan pengabdian pada Pesantren Bina Insan di kec. Bagan Pete kec. Alam Barajo, Kota Jambi" disusun dengan pertimbangan utama agar solusi/metode yang direncanakan dalam menyelesaikan sumber permasalahan yang dihadapi pihak pesantren dapat berjalan sesuai dari tujuan utama dari pengabdian ini.

\section{PEMBAHASAN}

Saat ini kegiatan sudah berlangsung, prioritas utama yang telah dilakukan adalah mempersiapkan bagaimana Budidaya Terpadu Ikan Dan Sayuran Melalui Metode Akuaponik dapat di implementasikan di pesantren mitra. Selanjutnya, telah mempersiapkan sarana pendukung berupa media yang dapat digunakan, selanjutnya telah dilakukan kegiatan berupa pelatihan dan demonstrasi langsung dilapangan dihadapan guru dan para santri di pesantren Al-Quran. dibawah ini.

Secara lebih rinci tahapan kerja pelaksanaan kegiatan dapat dilihat pada tabel 3 .

Tabel 3. Tabel Tahapan Kerja Pelaksanaan Kegiatan

\begin{tabular}{|c|c|c|c|c|}
\hline No & $\begin{array}{c}\text { Jenis } \\
\text { Kegiatan }\end{array}$ & Bentuk Kegiatan & Tujuan & Pelaksanaan \\
\hline 1. & $\begin{array}{l}\text { Pembinaan } \\
\text { Ketahanan } \\
\text { Pangan } \\
\text { Santri } \\
\text { Pesantren } \\
\text { Al-Quran } \\
\text { "Bina } \\
\text { Insan" Di } \\
\text { Masa } \\
\text { Pandemi } \\
\text { Covid-19 } \\
\text { Melalui } \\
\text { Budidaya } \\
\text { Terpadu } \\
\text { Ikan Dan } \\
\text { Sayuran } \\
\text { Melalui } \\
\text { Metode } \\
\text { Akuaponik }\end{array}$ & $\begin{array}{ll}\text { a. } & \text { Pengurusan } \\
& \text { surat } \\
\text { perizinan }\end{array}$ & & $\begin{array}{l}\text { Sudah } \\
\text { dilaksanakan }\end{array}$ \\
\hline
\end{tabular}




\begin{tabular}{|c|c|c|c|c|}
\hline & $\begin{array}{l}\text { Pembinaan } \\
\text { Ketahanan } \\
\text { Pangan } \\
\text { Santri } \\
\text { Pesantren } \\
\text { Al-Quran } \\
\text { "Bina Insan" } \\
\text { Di Masa } \\
\text { Pandemi } \\
\text { Covid-19 } \\
\text { Melalui } \\
\text { Budidaya } \\
\text { Terpadu } \\
\text { Ikan Dan } \\
\text { Sayuran } \\
\text { Melalui } \\
\text { Metode } \\
\text { Akuaponik }\end{array}$ & $\begin{array}{ll}\text { b. } & \text { Survei } \\
& \text { pendahuluan }\end{array}$ & $\begin{array}{l}\text { Diperlukan untuk } \\
\text { mendapatkan } \\
\text { informasi apakah } \\
\text { sumber daya } \\
\text { yang dimiliki } \\
\text { oleh mitra telah } \\
\text { memadai atau } \\
\text { Tidak untuk } \\
\text { digunakan pada } \\
\text { fase } \\
\text { Pengembangan } \\
\text { selanjutnya } \\
\text { Mengetahui sebab } \\
\text { dan akibat yang } \\
\text { ditimbulkan dari } \\
\text { kegiatan yang } \\
\text { akan di } \\
\text { implementasikan } \\
\text { dan } \\
\text { Mengetahui } \\
\text { keinginan/ apa } \\
\text { yang diharapkan } \\
\text { oleh mitra }\end{array}$ & $\begin{array}{l}\text { Sudah } \\
\text { dilaksanakan }\end{array}$ \\
\hline & & $\begin{array}{ll}\text { c. } & \text { Rakor tim } \\
\text { pelaksana dan } \\
\text { pengurus } \\
\text { (Mitra) }\end{array}$ & & $\begin{array}{l}\text { Sudah } \\
\text { dilaksanakan }\end{array}$ \\
\hline & & $\begin{array}{ll}\text { d. } & \begin{array}{l}\text { Penyusunan } \\
\text { rencana } \\
\text { kerja }\end{array} \\
\end{array}$ & & $\begin{array}{l}\text { Sudah } \\
\text { dilaksanakan }\end{array}$ \\
\hline & & $\begin{array}{ll}\text { e. } & \text { Perancangan } \\
\text { dan Pembuatan } \\
\text { Budidaya } \\
\text { Terpadu Ikan } \\
\text { Dan Sayuran } \\
\text { Melalui Metode } \\
\text { Akuaponik }\end{array}$ & $\begin{array}{l}\text { Menterjemahkan } \\
\text { keinginan mitra } \\
\text { ke Dalam } \\
\text { pelaksana } \\
\text { kegiatan } \\
\text { pengabdian }\end{array}$ & $\begin{array}{l}\text { Sudah } \\
\text { dilaksanakan } \\
\text { (Dalam Proses } \\
\text { Penyempurnaan) }\end{array}$ \\
\hline & & d. Evaluasi awal & & $\begin{array}{l}\text { Sudah } \\
\text { dilaksanakan }\end{array}$ \\
\hline 2. & $\begin{array}{l}\text { Penyuluhan } \\
\text { tentangan } \\
\text { Budidaya } \\
\text { Terpadu } \\
\text { Ikan Dan } \\
\text { Sayuran } \\
\text { Melalui } \\
\text { Metode } \\
\text { Akuaponik }\end{array}$ & $\begin{array}{ll}\text { g. } & \text { Penyuluhan dan } \\
\text { pengenalan } \\
\text { Budidaya } \\
\text { Terpadu Ikan } \\
\text { Dan Sayuran } \\
\text { Melalui Metode } \\
\text { Akuaponik }\end{array}$ & $\begin{array}{l}\text { Memperkenalkan } \\
\text { serta } \\
\text { menjelaskan } \\
\text { kepada guru dan } \\
\text { mitra tentang } \\
\text { Budidaya } \\
\text { Terpadu Ikan } \\
\text { Dan Sayuran } \\
\text { Melalui Metode } \\
\text { Akuaponik }\end{array}$ & $\begin{array}{l}\text { Sudah } \\
\text { dilaksanakan }\end{array}$ \\
\hline
\end{tabular}




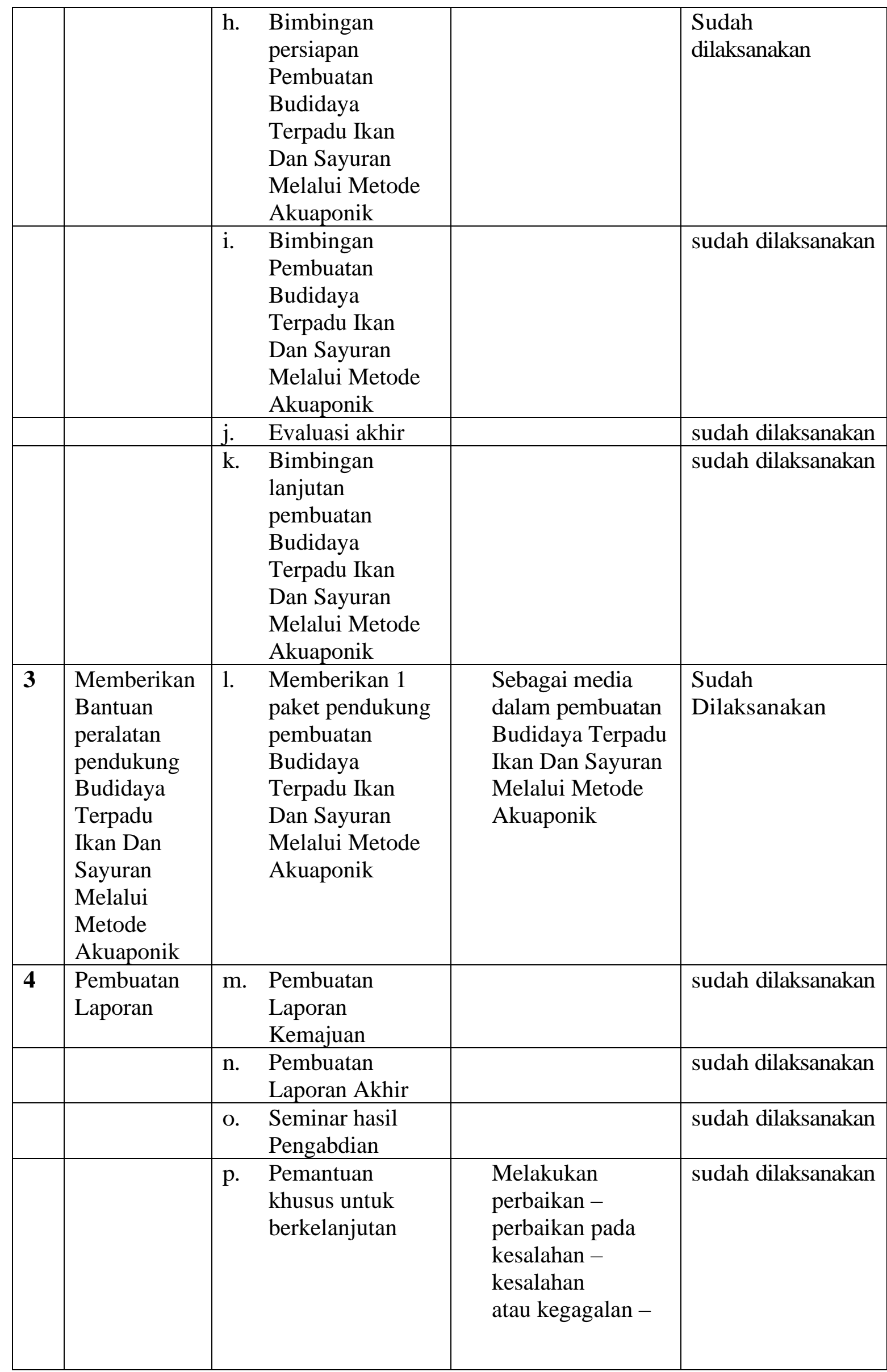




\begin{tabular}{|l|l|l|}
\hline & & kegagalan yang \\
& & timbul dalam \\
& pembuatan & \\
& Budidaya Terpadu & \\
& Ikan Dan Sayuran & Melalui Metode \\
& & Akuaponik \\
& & \\
\hline
\end{tabular}
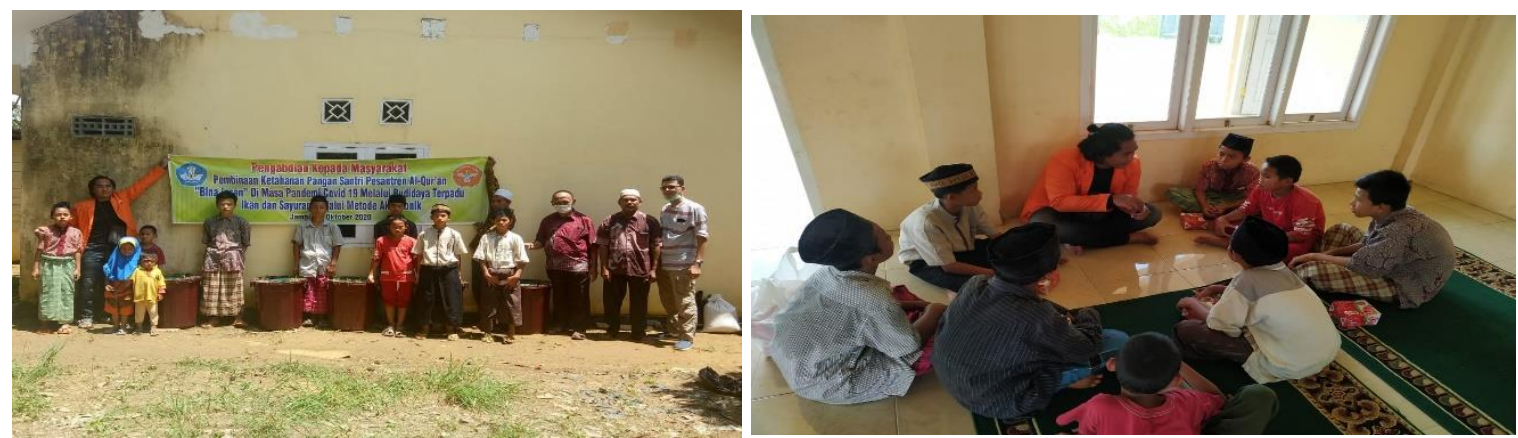

Gambar 3. Kegiatan Pelaksanaan Pengabdian di Pesantren Mitra

\section{KESIMPULAN}

Kesimpulan sementara dari beberapa kegiatan adalah adanya motivasi yang tinggi dari para guru dan santri di pesantren mitra untuk budidaya terpadu ikan dan sayuran melalui metode akuaponik dalam rangka meningkatkan ketahanan pangan guru dan santri di pesantren mitra, dimana sebelumnya guru dan santri di pesantren tersebut tidak mengetahui bagaimana budidaya terpadu ikan dan sayuran melalui metode akuaponik bagi menjaga ketahanan pangan masyarakat khususnya bagi guru dan santri di pesantren mitra di masa pandemi COVID 19.

Namun, agar kegiatan ini berjalan lebih baik lagi. Perlu adanya peranan stakeholder khusus pemerintah Kota Jambi yang terkait dengan meningkatan ketahanan pangan masyarakat dimasa pandemi COVID 19 khususnya santri di pesantren mitra ini, dengan memberikan pengetahuan dan pelatihan sehingga kedepannya masyarakat yang ada di Kota Jambi bisa menjaga ketahanan pangan sehingga lebih siap lagi untuk menghadapi pembatasan sosial dimasa pendemi COVID 19 bagi memutuskan mata rantai penyebaran dari Virus COVID 19.

\section{UCAPAN TERIMAKASIH}

Terima kasih kami ucapkan kepada Rektor, Ketua Lembaga Penelitian dan pengabdian dan Ketua Pascasarjana Universitas Jambi atas pendanaan kegiatan pengabdian ini sebagi bentuk pembinaan dosen di Perguruan Tinggi Universitas Jambi sehingga pengabdian ini dapat terselenggara dengan baik serta atas dukungan dan arahannya dalam kegiatan pengabdian ini. Terima kasih pula kami ucapakan kepada ketua Yayasan pesantren Bina Insan yang telah memberikan ijin untuk dapat melaksanakan kegiatan pengabdian masyarakat ini. 


\section{DAFTAR PUSTAKA}

SB-IPB, 2020, “ Strategi Ketahanan Pangan di Era New Normal Pandemi Covid 19” Diperoleh 01 September 2020 Dari "http://sb.ipb.ac.id/en/strategi-ketahanan-pangan-di-era-newnormal-pandemi-covid-19-2/

Alamsyah, Emrald, 2020, "Sinergi Antar Sektoral Kunci Ketahanan Pangan Era New Normal ", Diperoleh 01 September 2020 Dari https://republika.co.id/berita/qbv4op349/sinergi-antarsektoral-kunci-ketahanan-pangan-era-emnew-normalem 